\title{
PENGARUH PENGGUNAAN ASI PADA PERAWATAN LUKA PERINEUM \\ TERHADAP LAMA WAKTU PENYEMBUHAN LUKA PERINEUM \\ PADA IBU NIFAS DI KLINIK DEWI SESMERA MEDAN
}

\author{
Verawaty Fitrinelda Silaban ${ }^{1}$, Pirda Ardianita ${ }^{2}$, Kristina Sianipar $^{3}$ \\ Siti Nuravina ${ }^{4}$, Febrianti ${ }^{5}$ \\ S1 Kebidanan, Fakultas Keperawatan Dan Kebidanan Universitas Prima Indonesia \\ Gg. Madrasah Sei Agul Kec. Medan Barat, Kota Medan Sumatera Utara, Indonesia 20117 \\ verawatysilaban92@gmail.com, pirdaardianita24@gmail.com, kristinasianipar9@gmail.com, \\ Nuravina137@gmail.com,antif597@gmail.com
}

\begin{abstract}
Labor could results in perineal tears in both primigravidas and multigravidas with a rigid perineum. Prolonged wound healing time and improper care techniques can lead to postpartum infection. The healing phase is ideally the process of wound healing in restoring the original tissue, if this is not possible, scar tissue will form. Breast milk can be used for the treatment of perineal wounds because it contains anti-inflammatory molecules called specialized pro-resolving mediators (SPMs) as bioactive substances contained in breast milk. The purpose of this study was to determine the effect of using breast milk in the treatment of perineal wounds on the duration of healing of perineal wounds in postpartum mothers at Clinik Dewi Sesmera, Medan City in 2021. This research method was a true experimental design. The population in this study were 50 postpartum mothers with lacerations of the perineum, the sampling technique was consecutive sampling. Data analysis was performed using the SPSS statistical test with t test. Based on the results of the T test research, it was found that the $p$ value of $0.001<0.05$ and the t test of 5.639> t table 2.0106 ( $t$ table 0.025, $d f=48$ ), which means that there is an effect of using breast milk in the treatment of perineal wounds on the length of time. Healing Time for Postpartum Mother at Dewi Sesmera Clinic, Medan.
\end{abstract}

Keyword :Breast Milk, Perineal Wounds, Long Healing Time

\begin{abstract}
ABSTRAK
Persalinan dapat menyebabkan terjadinya robekan jalan lahir baik bagi ibu pertama kali melahirkan maupun ibu yang telah melahirkan beberapa kali dengan perineum yang kaku. Lamanya waktu penyembuhan luka dan tehnik perawatan yang tidak tepat dapat mengakibatkan infeksi postpartum. Waktu penyembuhan umumnya merupakan proses penyembuhan luka untuk memulihkan seperti jaringan semula, bila tidak memungkinkan maka akan terbentuk jaringan parut. ASI bisa digunakan untuk perawatan luka perineum karena mengandung molekul anti inflamasi yang disebut dengan specialized pro-resolving mediators (SPMs) sebagai zat bioaktif yang terkandung dalam ASI. Tujuan penelitian ini Untuk mengetahui pengaruh penggunaan ASI pada perawatan luka perineum terhadap lama waktu penyembuhan luka perineum pada ibu nifas di Kinik Dewi Sesmera Kota Medan Tahun 2021. Metode penelitian ini adalah desain eksperimen murni. Populasi dalam penelitian ini adalah ibu nifas dengan laserasi luka perineum berjumlah 50 orang, teknik pengambilan sampel dengan teknik consecutive sampling. Analisa data dilakukan dengan menggunakan uji statistik SPSS dengan uji t. Berdasarkan hasil penelitian Uji T didapatkan nilai $p$ value sebesar 0,001 <0,05 dan uji thitung sebesar 5,639 > t tabel 2,0106 (tabel t 0,025, df $=48$ ), yang berarti bahwa ada Pengaruh Penggunaan Asi Pada Perawatan Luka Perineum Terhadap Lama Waktu Penyembuhan Pada Ibu Nifas di Klinik Dewi Sesmera Medan.
\end{abstract}

Kata kunci : ASI, Luka Perineum, Lama Waktu Penyembuhan 


\section{PENDAHULUAN \\ Latar Belakang}

Persalinan dapat menyebabkan robekan pada perineum baik pada primigravida maupun multigravida, dengan perineum yang kaku Seringkali robekan perineum terjadi sewaktu melahirkan dan penaganannya merupakan masalah kebidanan. Robekan pada perineum ini bisa terjadi secara spontan serta dapat juga terjadi karena dilakukannya episiotomi dalam upaya melebarkan jalan lahir (Utami, 2017).

Robekan perineum ini merupakan media yang baik bagi kuman untuk berkembang biak jika tidak mendapatkan perawatan yang tepat. Hal ini juga merupakan salah satu penyebab bervariasinya lama penyembuhan luka perineum tersebut. Lamanya waktu penyembuhan luka dan tehnik perawatan yang tidak tepat dapat mengakibatkan infeksi postpartum (JNPK, R, 2017)

Berdasarkan data dari World Health Organization (WHO) hampir $90 \%$ proses persalinan normal mengalami robekan perineum baik secara spontan ataupun episiotomi. Di seluruh dunia robekan perineum terjadi hampir 2,7 juta kasus pada ibu bersalin. Angka ini masih akan terus meningkat hingga 6,3 juta di tahun 2024, jika tidak mendapat perhatian dan penanganan yang baik. Di negara Asia angka kejadian luka robekan perineum menjadi masalah yang cukup tinggi dalam masyarakat (Ghassani dkk, 2020).

Berdasarkan Data Survey Demografi Kesehatan Indonesia (SDKI) menunjukan bahwa di Indonesia robekan atau rupture perineum dialami oleh $75 \%$ ibu melahirkan. Prevalensi ibu bersalin yang mengalami robekan perineum di Indonesia pada golongan umur 25-30 tahun yaitu $24 \%$, serta pada ibu 32-39 tahun sebesar $62 \%$. Pada tahun 2017 ditemukan bahwa dari total 1951 kelahiran spontan pervaginam, 57\% ibu mendapatkan jahitan perineum, 28\% karena episiotomi dan 29\% karena robekan spontan (Depkes RI, 2019). Serta jumlah AKI di Sumatera Utara yaitu sebesar 85/100.000 kelahiran hidup. Di kota Medan tercatat jumlah kematian ibu pada tahun 2016 yaitu 239 kematian (Dinas \& Prov.SU, 2019).

Robekan perineum yang terjadi pada saat proses persalinan dapat mengakibatkan infeksi jika tidak ditangani dengan tepat. Fase penyembuhan secara ideal merupakan proses penyembuhan luka dalam memulihkan seperti jaringan semula. Penggunaan bahan yang tepat dalam perawatan luka perineum merupakan teknik yang benar, jika penggunaan bahan yang kurang tepat dapat menyebabkan luka sulit sembuh atau penyembuhan lama dan menyebabkan infeksi (Utami, 2017).

ASI bisa digunakan untuk perawatan luka perineum karena mengandung molekul anti inflamasi yang disebut dengan specialized proresolving mediators (SPMs) sebagai zat bioaktif yang terkandung dalam ASI, Molekul bioaktifnya berguna untuk menyembuhkan luka terutama pemulihan cidera. ASI secara epidemiologis dan klinik mengandung antibody, anti inflamasi dan antioksi dan seperti Vitamin A,B, E, enzimekatalase, dan glutathione peroxide, serta sangat kaya akan sel darah putih yang memiliki kemampuan untuk membunuh kuman secara langsung maupun tidak langsung (Admasari, 2017).

Hasil penelitian menunjukkan bahwa ada berbagai media yang pernah dilakukan untuk perawatan luka perineum, Dewi (2019) dengan judul Pengaruh pemberian telur ayam broiler terhadap penyembuhan luka perineum pada ibu nifas, diperoleh hasil rata-rata penyembuhan yaitu 5 - 6 hari sementara pada kelompok kontrol ratarata penyembuhan $10-12$ hari. Penelitian Fadelika dkk (2018) dengan judul pengaruh konsumsi ikan lele terhadap lama penyembuhan luka jahitan perineum, diperoleh hasil bahwa ibu yang mengkonsumsi ikan lele kesembuhan lebih cepat 4 hari dibandingkan dengan yang tidak diberikan perlakuan (Fadelika, Rahayu, \& Sendra, 2018)

Yuniarti (2018), dengan judul efektivitas salep jintan hitam pada proses penyembuhan luka perineum rupture ibu nifas diperoleh hasil rata-rata kesembuhan luka perineum adalah selama 7 hari, sementara kelompok kontrol rata-rata kesembuhan selama 10 - 12 hari. Hasil penelitian Triana dkk (2020), dengan judul efektivitas air rebusan daun binahong terhadap penyembuhan rupture perineum pada ibu bersalin diperoleh hasil rata rata kesembuhan yaitu 8 hari.

Berdasarkan survey awal yang dilakukan di klinik Dewi Sesmera Kota Medan, pada ibu nifas yang mengalami robekan perineum derajat II sebanyak 31 orang, data tersebut menunjukan bahwa kasus ibu dengan luka robekan perineum masih cukup tinggi. Melihat kondisi tersebut peneliti terarik untuk melakukan penelitian dengan judul "Pengaruh Penggunaan Asi Para Perawatan Luka Perineum Terhadap Lama Waktu Penyembuhan Pada Ibu Nifas Di Klinik Dewi Sesmera Medan Tahun 2021"

Tujuan dari penelitian ini adalah Diketahui pengaruh penggunaan ASI pada perawatan luka perineum terhadap lama waktu 
penyembuhan luka perineum pada ibu nifas di Kinik Dewi Sesmera Kota Medan Tahun 2021.

\section{METODE}

Metode penelitian ini adalah desain eksperimen sederhana. Populasi dalam penelitian ini adalah ibu nifas dengan laserasi luka perineum berjumlah 50 orang, teknik pengambilan sampel dengan teknik consecutive sampling. Analisa data dilakukan dengan menggunakan uji statistik SPSS dengan uji t.

\section{HASIL}

\section{Karakteristik Responden}

Berdasarkan hasil penelitian dapat dilihat bahwa umur responden $<20$ tahun sebanyak 10 orang (20\%), umur 20 - 35 tahun sebanyak 38 orang $(76 \%)$ dan yang berumur $>35$ tahun sebanyak 2 orang $(4 \%)$. Responden dengan pendidikan SMP sebanyak 12 orang (24\%), responden dengan pendidikan SMA sebanyak 31 orang $(62 \%)$ dan responden dengan pendidikan Diploma/Sarjana sebanyak 7 orang (14\%) serta tidak ditemukan responden dengan pendidikan SD. Paritas responden primipara berjumlah 32 orang $(64 \%)$, skundipara berjumlah 14 orang (28\%) dan multipara berjumlah 4 orang $(8 \%)$.

Tabel 1. Distribusi Frekuensi Karakteristik Responden

\begin{tabular}{|c|l|c|c|}
\hline $\begin{array}{c}\text { N } \\
\mathrm{O}\end{array}$ & Karakteristik & $\begin{array}{c}\text { Frekuens } \\
\mathrm{i}\end{array}$ & $\begin{array}{c}\text { Persentas } \\
\mathrm{e}\end{array}$ \\
\hline & Umur & & \\
1 & $<20$ tahun & 10 & 20 \\
2 & $20-35$ tahun & 38 & 76 \\
3 & $>35$ tahun & 2 & 4 \\
\hline & \multicolumn{1}{|c|}{ Total } & 50 & 100 \\
\hline & Pendidikan & & \\
1 & SD & - & - \\
2 & SMP & 12 & 24 \\
3 & SMA & 31 & 62 \\
4 & Diploma/Sarjan & 7 & 14 \\
& a & & \\
\hline & \multicolumn{1}{|c|}{ Total } & 50 & 100 \\
\hline & Paritas & & \\
1 & Primipara & 32 & 64 \\
2 & Skundipara & 14 & 28 \\
3 & Multipara & 4 & 8 \\
\hline \multicolumn{2}{|c|}{ Total } & 50 & 100 \\
\hline
\end{tabular}

\section{Analisa Univariat}

\section{Lama Waktu Penyembuhan Luka Perineum dengan Menggunakan ASI}

Tabel 2. Lama Waktu Penyembuhan Luka

Perineum dengan Menggunakan ASI

\begin{tabular}{|c|c|c|c|c|}
\hline $\begin{array}{c}\text { Waktu } \\
\text { Penyembuh } \\
\text { an Luka }\end{array}$ & $\begin{array}{c}\text { Mean } \\
\text { Media } \\
\text { n }\end{array}$ & S.D & $\begin{array}{c}\text { Min- } \\
\text { Mak } \\
\text { S }\end{array}$ & $\begin{array}{c}95 \% \\
\text { CI }\end{array}$ \\
\hline ASI & $\begin{array}{l}7 \\
7\end{array}$ & $\begin{array}{c}1,00 \\
0\end{array}$ & $6-9$ & $\begin{array}{c}0,978 \\
- \\
2,062\end{array}$ \\
\hline
\end{tabular}

Berdasarkan tabel di atas dapat dilihat bahwa rata-rata lama waktu penyembuhan luka dengan menggunakan ASI adalah dengan nilai median 7 hari dan nilai standart deviasinya sebesar 1,000 , paling cepat adalah 6 hari dan paling lama adalah 9 hari. Berdasarkan nilai 95\% CI, diyakini bahwa $95 \%$ waktu penyembuhan luka perineum yang menggunakan ASI berkisar 0,978 -2,062.

Tabel 3 Lama Waktu Penyembuhan Luka

Perineum dengan Menggunakan Salep Jintan Hitam

\begin{tabular}{|c|c|c|c|c|}
\hline $\begin{array}{c}\text { Waktu } \\
\text { Penyembuh } \\
\text { an Luka }\end{array}$ & $\begin{array}{c}\text { Mean } \\
\text { Media } \\
\text { n }\end{array}$ & S.D & $\begin{array}{c}\text { Min- } \\
\text { Mak } \\
\text { Sas }\end{array}$ & $\begin{array}{c}\text { 95\% } \\
\text { CI }\end{array}$ \\
\hline $\begin{array}{c}\text { Salep Jintan } \\
\text { Hitam }\end{array}$ & 8 & 1,02 & $7-10$ & $\begin{array}{c}0,978 \\
- \\
2,062\end{array}$ \\
\hline
\end{tabular}

Berdasarkan tabel di atas dapat dilihat bahwa rata-rata lama waktu penyembuhan luka dengan menggunakan salep jintan hitam adalah dengan nilai median 8 hari dan nilai standart deviasinya sebesar 1,021 , paling cepat adalah 7 hari dan paling lama adalah 10 hari. Berdasarkan nilai 95\% CI, diyakini bahwa 95\% waktu penyembuhan luka perineum yang menggunakan ASI berkisar 0,978-2,062.

\section{Analisa Bivariat}

Tabel 4 Pengaruh Penggunaan Asi Pada Perawatan Luka Perineum Terhadap Lama Waktu Penyembuhan Pada Ibu Nifas

\begin{tabular}{|c|c|c|c|c|c|c|c|}
\hline & $\begin{array}{c}\text { Waktu } \\
\text { Penye } \\
\text { mbuha } \\
\text { n }\end{array}$ & $\begin{array}{l}M \\
\text { ea } \\
n\end{array}$ & $\begin{array}{l}\text { Std. } \\
\text { Devi } \\
\text { atio } \\
n\end{array}$ & $\begin{array}{c}\mathrm{St} \\
\mathrm{d} . \\
\mathrm{Er} \\
\text { ro } \\
\mathrm{r}\end{array}$ & $\mathrm{N}$ & $\mathrm{t}$ & $\begin{array}{c}\mathrm{P} . \\
\mathrm{Va} \\
\mathrm{lu} \\
\mathrm{e}\end{array}$ \\
\hline $\begin{array}{c}\text { Kelo } \\
\text { mpo } \\
\text { k }\end{array}$ & $\begin{array}{c}\text { Eksper } \\
\text { imen } \\
\text { ASI }\end{array}$ & 7 & $\begin{array}{c}1,00 \\
0\end{array}$ & $\begin{array}{c}0, \\
20 \\
0\end{array}$ & $\begin{array}{l}2 \\
5\end{array}$ & $\begin{array}{c}5, \\
63 \\
9\end{array}$ & $\begin{array}{c}0, \\
00 \\
1\end{array}$ \\
\hline
\end{tabular}




\begin{tabular}{|c|c|c|c|c|}
\hline $\begin{array}{c}\text { Kontro } \\
\text { 1 Salep } \\
\text { jintan } \\
\text { hitam }\end{array}$ & 8 & $\begin{array}{c}1,02 \\
1\end{array}$ & $\begin{array}{c}0 \\
20 \\
4\end{array}$ & $\begin{array}{l}2 \\
5\end{array}$ \\
\hline
\end{tabular}

Berdasarkan tabel di atas menunjukkan bahwa dari 25 responden dari Kelompok Eksperimen yang diteliti diperoleh rata-rata waktu lama penyembuhan luka pereineum adalah 7 hari sedangkan pada Kelompok Kontrol adalah 8 hari artinya bahwa Kelompok Eksperimen lebih cepat 1 hari dibandingkan dengan Kelompok Kontrol. Hasil uji statistik dengan uji t independen dengan $a=0,05$ diperoleh nilai $p$ value sebesar 0,001 yang berarti nilai $p$ value $<0,05$, yang berarti bahwa ada Pengaruh Penggunaan ASI pada perawatan luka perineum terhadap lama waktu penyembuhan pada ibu nifas di Klinik Dewi Sesmera Medan.

\section{PEMBAHASAN}

Proses penyembuhan luka perineum pada ibu nifas dipengaruhi banyak faktor, Yaitu faktor internal dan eksternal. Faktor-faktor eksternal yang mempengaruhi penyembuhan luka meliputi : lingkungan, tradisi, pengetahuan, sosial ekonomi, kondisi ibu, pemberian antibiotik, dan personal hygiene. Sedangkan faktor-faktor internal yang mempengaruhi penyembuhan luka adalah usia, trauma jaringan atau infeksi, penanganan jaringan, hemoragi, hipovolemia, faktor lokal edema, defisit nutrisi, personal hygiene, defisit oksigen, jenis persalinan, jenis luka jahitan luka perineum, dan kadar hemoglobin (Wulandari, 2018).

ASI bisa digunakan untuk perawatan luka perineum karena mengandung molekul anti inflamasi yang disebut dengan specialized proresolving mediators (SPMs) sebagai zat bioaktif yang terkandung dalam ASI. ASI mengandung faktor proteksi yang bukan termasuk sistem imunologik seperti lisozim, laktoferin, oligosakarida, asam lemak yang semuanya berperan. Selain sebagai faktor protektif juga mengandung beberapa faktor untuk pertumbuhan serta pematangan sistem imun dan metabolik ASI juga mengandung berbagai komponen antiinflamasi seperti vitamin $\mathrm{A}, \mathrm{C}$, dan $\mathrm{E}$, sitokin, enzim dan inhibitor enzim, prostaglandin $\mathrm{E}$ dan faktor pertumbuhan (Admasari, 2017).

ASI secara epidemiologis dan klinik mengandung antibody, anti inflamasi dan antioksi dan seperti Vitamin A,B, E, enzimekatalase, dan glutathione peroxide, serta sangat kaya akan sel darah putih yang memiliki kemampuan untuk membunuh kuman secara langsung maupun tidak langsung (Arnadottir, 2016).
Hasil penelitian ini menunjukan bahwa responden tergolong dalam Usia Produktif yaitu 20 - 35 tahun memiliki frekuensi terbanyak sebesar 76\%. Meskipun usia ibu dalam usia produktif apabila jarang berolahraga seperti senam kegel atau senam hamil dan rajin berhubungan suami istri saat sebelum hamil, ibudapat mengalami robekan pada perineum. Selain itu juga, kelenturan pada jalan lahir dapat berkurang apabila ibu jarang berolahraga dan pada daerah genetalia sering terkena infeksi (Suparti, 2018). Hal ini sejalan dengan penelitian terdahulu yang dilakukan oleh Siti Haniyah dkk tahun 2019, menyatakan bahwa jalan lahir akan lentur pada perempuan yang rajin berolahraga atau rajin bersenggama. Olahraga yang dianjurkan yaitu renang karena dengan berenang dapat melenturkan otot - otot sekitarnya.

Hasil penelitian ini menunjukan bahwa pendidikan responden mayoritas ibu nifas SMA sebanyak 31 orang $(62 \%)$. robekan jalan lahir pada responden dengan tingkat pendidikan SMA terdapat 8 orang yang kurang memahami tentang perawatan luka perineum, dan 23 orang memahami tentang perawatan luka perineum. Menurut asumsi peneliti tingkat pendidikan berpengaruh terhadap perawatan perineum yang dilakukan ibu, ibu nifas dengan tingkat pendidikan yang baik akan memiliki pengetahuan yang lebih besar, jika dibandingkan dengan ibu nifas yang berpendidikan rendah. Hal tersebut sejalan dengan penelitian terdahulu yang dilakukan oleh Nurrahmaton 2018, dengan hasil nilai $\rho$ 0,001 < 0,05 yang artinya secara statistik ada hubungan yang signifikan antara pengetahuan ibu tentang perawatan luka perineum (Nurrahmaton \& Sartika, 2018).

Hasil dari penelitian ini memperlihatkan bahwa paritas responden yang terbanyak adalah primipara yaitu sebanyak $64 \%$. Status primipara biasanya memiliki perineum lebih kaku sehingga rentan terjadinya robekan. Perineum yang kaku kemungkinan besar tidak dapat beradaptasi terhadap regangan yang berlebihan sehingga dapat mengakibatkan robekan perineum. Selain itu, ibu yang belum memiliki pengalaman dalam melahirkan sebelumnya belum mengetahui seperti teknik mengejan yang benar, posisi persalinan yang benar serta kurangnya informasi yang diberikan pada ibu selama masa hamil mengenai pencegahan robekan perineum. Namun, tidak menutup kemungkinan ibu dengan multipara dan grandemultipara dapat mengalami robekan perineum. Hal tersebut, terjadi karena setiap orang memiliki tingkat keelastisan perineum yang 
berbeda (Saifuddin, 2013). Hal ini sejalan dengan penelitian yang dilakukan oleh Elisa tahun 2016, bahwa pada primipara $84,9 \%$ dari 107 ibu yang bersalin mengalami laserasi jalan lahir spontan, hal itu disebabkan karena pada primipara otot otot perineun masih kaku karena belum pernah di lalui oleh bayi sehingga otot perineum belum merenggang.

Berdasarkan tabel 2 dapat dilihat bahwa rata-rata lama waktu penyembuhan luka dengan menggunakan ASI adalah dengan nilai median 7 hari dan nilai Standart Deviasinya sebesar 1,000, paling cepat adalah 6 hari dan paling lama adalah 9 hari. Berdasarkan nilai 95\% CI, diyakini bahwa 95\% waktu penyembuhan luka perineum yang menggunakan ASI berkisar 0,978 - 2,062. Hasil ini sesuai dengan penelitian Mutmainnah (2019) dengan judul pengaruh penggunaan ASI pada perawatan luka perineum dengan lama waktu penyembuhan luka perineum dengan hasil penelitian harga $\mathrm{F}$ hitung 108,195 dengan signifikansi sebesar $0,001<0,05$, yaitu terdapat pengaruh yang signifikan antara penggunaan ASI dengan lama waktu penyembuhan luka perineum (Mutmainnah, 2019).

Berdasarkan tabel 3.3 dapat dilihat bahwa rata-rata lama waktu penyembuhan luka dengan menggunakan salep jintan hitam adalah dengan nilai median 8 hari dan nilai Standart Deviasinya sebesar 1,021, paling cepat adalah 7 hari dan paling lama adalah 10 hari. Berdasarkan nilai $95 \%$ CI, diyakini bahwa 95\% waktu penyembuhan luka perineum yang menggunakan ASI berkisar 0,978 - 2,062. Hal tersebut sejalan dengan penelitian yang dilakukan oleh Yuniarti (2018), dengan judul efektivitas salep jintan hitam pada proses penyembuhan luka perineum rupture ibu nifas diperoleh hasil rata-rata kesembuhan luka perineum ditemukan mulai hari ke 7 , sementara kelompok kontrol rata-rata kesembuhan selama 10 -12 hari.

Berdasarkan tabel 4 hasil uji statistik menggunakan Uji $\mathrm{T}$ bahwa dari 25 responden dari kelompok ASI yang diteliti diperoleh rata-rata waktu lama penyembuhan luka pereineum adalah 7 hari sedangkan pada kelompok salep jintan hitam adalah 8 hari artinya bahwa kelompok ASI lebih cepat 1 hari dibandingkan dengan salep jintan hitam. Hasil uji statistik dengan uji $t$ independen dengan $a=0,05$ diperoleh nilai $p$ value sebesar 0,001 yang berarti nilai $p$-value < 0,05 , yang berarti bahwa ada pengaruh penggunaan ASI pada perawatan luka perineum terhadap waktu penyembuhan pada ibu nifas di Klinik Dewi Sesmera Medan.

Hal tersebut sejalan dengan penelitian yang dilakukan oleh Dwi yani ratna dewi tahun 2018, menyimpulkan bahwa ada pengaruh pemberian topikal ASI terhadap lama pelepasan tali pusat bayi baru lahir yang mendapatkan topikal ASI berpeluang 1,42 (42,66 jam) mengalami pelepasan tali pusat lebih cepat dibandigkan dengan bayi baru lahir dengan tidak diberikan topikal ASI. Sejalan juga dengan penelitian terdahulu yang dilakukan oleh Masjidah tahun 2020 didapatkan hasil rata - rata waktu lepas tali pusat bayi yang dibungkus kasa steril adalah 2 hari sedangkan rata - rata waktu lepas tali pusat bayi yang diwarat dengan kasa topikal ASI lebih cepat yaitu 1 hari.

Sejalan juga dengan penelitian yang dilakukan oleh Andi St Umrah tahun 2017 dengan judul pengaruh pemberian topikal ASI terhadap waktu perawatan tali pusat pada bayi baru lahir, yang mengatakan bahwa perawatan tali pusat akan lebih cepat mengering jika menggunakan ASI karena ASI mengandung anti infeksi dan anti infamasi yang membuat tali pusat lebih cepat mengering jika dioleskan dengan menggunakan ASI.

Penelitian Dewi (2019) dengan judul Pengaruh pemberian telur ayam broiler terhadap penyembuhan luka perineum pada ibu nifas, protein dari telur dibutuhkan untuk membentuk jaringan otot tubuh agar mempercepat proses penyembuhan luka, diperoleh hasil rata-rata penyembuhan yaitu $5-6$ hari sementara pada kelompok kontrol rata-rata penyembuhan $10-12$ hari. Hasil penelitian Triana dkk tahun (2020), dengan judul efektivitas air rebusan daun binahong terhadap penyembuhan rupture perineum pada ibu bersalin mengatakan bahwa diperoleh hasil rata - rata kesembuhan yaitu 8 hari.

\section{KESIMPULAN}

Berdasarkan hasil penelitian yang dilakukan terhadap responden di Klinik Dewi Sesmera, Responden yang diberi perlakuan ASI rata-rata lama waktu penyembuhan luka perineum adalah 7 hari dan Responden yang diberi perlakuan Salep Jintan Hitam rata-rata lama waktu penyembuhan luka perineum adalah 8 hari. Hasil uji statistik dengan uji t didapatkan nilai pvalue sebesar 0,001 $<0,05$ dan uji t hitung sebesar 5,639 > t tabel 2,0106 (tabel t 0,025, df =48), yang berarti bahwa ada Pengaruh Penggunaan Asi Pada Perawatan Luka Perineum Terhadap Lama Waktu 
Penyembuhan Pada Ibu Nifas di Klinik Dewi Sesmera Medan.

\section{DAFTAR PUSTAKA}

1. Admasari, Y. Breast Milk As an Alternative for Postpartum Perinatal Care. Belitung Nursing Jurnal. Vol. 3, No. 3, Juni 2017.

2. Andi St. Umrah Pengaruh pemberian topikal asi terhadap waktu perawatan Tali pusat pada bayi baru lahir di puskesmas angkona Kecamatan angkona kabupaten luwu timur 2017.

3. Arnadottir H, Orr Sk, Dalli J, Serhan CN. Human milk propre mediators stimulate Resulution of acute infamation. Mucosal immunology, 2016.

4. Dewi, R. Pengaruh Pemberian Telur Ayam Broiler terhadap Penyembuhan Luka Perineum pada Ibu Nifas. Aceh Nutrition Journal. Volume 4, Nomor 2, Nopember 2019.

5. Elisa Hubungan Paritas Dengan Terjadinya Robekan Perineum Spontan Pada Persalinan Normal Volume 2 No. 02, Juli 2016.

6. Fadelika, M. P. Pengaruh Konsumsi Lele terhadap Lama Penyembuhan Luka Jahitan Perineum. Global Health Science. Volume 3, No. 1 Maret 2018.

7. Ghassani, M. Pengetahuan Ibu Nifas Mengenai Penyembuhan Luka Perineum Dengan Menggunakan Booklet. Jurnal Kebidanan. Vol. 6, No. 3, Juli 2020.

8. JNPK-KR. 2017. Asuhan Persalinan Normal \& Inisiasi Menyusui Dini. Jakarta: Depkes RI.

9. Masjidah. Perbedaan Perawatan Tali Pusat Menggunakan Kassa Topikal Asidengan Kassa Kering Terhadap Lama Waktu Pelepasan Tali Pusat Midwifery Care Journal,Vol. 1 No.4, Juli 2020.

10. Mutmainnah, A. U. And Noorbaya, S. (2019) "Pengaruh Penggunaan Asi Pada Perawatan Luka Periniem Dengan Lama Waktu Penyembuhan Luka Perinium",

11. Nurrahmaton 2018. Hubungan Pengetahuan Ibu Post Partum Tentang Perawatan Luka Perineumdengan Proses Penyembuhan Luka.

12. Profil Kesehatan Indonesia. 2019. Dinas Kesehatan Republik Indonesia.

13. Profil Kesehatan Sumatera Utara. 2019. Dinas Kesehatan Provinsi Sumatera Utara.
14. Rostika, T. dkk. Pengaruh Pemberian Rebusan Daun Sirih Merah Terhadap Waktu Penyembuhan Luka Perineum di Klinik Aster Kabupaten Karawang. Jurnal Ilmiah Kesehatan. Vol. 12, No. 2. September 2020.

15. Saifuddin, Bari Abdul. (2013). Pelayanan Kesehatan Maternal dan Neonatal. Jakarta: PT Bina Pustaka Sarwono Prawirohardjo.

16. Suparti, S. Hubungan Berat BadanBayi Baru Lahir TerhadapRuptur Perineum pada Ibu BersalinDi KPD" Sumber Waras" Sukerejo KecamatanMusuk Boyolali Tahun2018. Jurnal Kebidanan Indonesia: Journal of Indonesia Midwifery, 10(1), 147-57.

17. Siti Haniyah Dkk 2019 Hubungan Umur Ibu Dan Paritas Dengan Derajat Laserasi Perineum di RSUD DR. R TARONADIBRATA Purbalingga.

18. Triana, I. Fitri, M. Retno, W. Efektivitas Air Rebusan Daun Binahong terhadap Penyembuhan Ruptur Perineum pada Ibu Bersalin di Puskesmas Menes Kabupaten Pandeglang. Journal for Quality in Women's Health. Vol. 3, No. 2, September 2020.

19. Utami, N. H. 2017. Hubungan Perawatan Perineum dengan Kesembuhan Luka Perineum pada Ibu Nifas di Klinik Bersalin Widuri Sleman. Naskah Publikasi. Fakultas Ilmu Kesehatan. Universitas Aisyiyah Yogyakarta.

20. Yuniarti. Efektivitas Salep Jintan Hitam (Nigella Sativa) pada Proses Penyembuhan Luka Perineum Rupture Ibu Nifas. Jurnal Kesehatan Manarang. Volume 4, Nomor 2. Desember 2018.

21. Wulandari 2018. Perbandingan Penyembuhan Luka Perineum Pada Ibu Postpartum Dengan Madu Vs Povidon Iodin. 